Available online at GSC Online Press Directory

GSC Biological and Pharmaceutical Sciences

e-ISSN: 2581-3250, CODEN (USA): GBPSC2

Journal homepage: https://www.gsconlinepress.com/journals/gscbps

(RESEARCH ARTICLE)

\title{
Effect of age on the pharmacokinetics of sulphadimidine in West African Dwarf (WAD) goats following a single intramuscular administration
}

\author{
Agbo Joseph Odeh *, Onyeyili Patrick Azubuike, Saganuwan Alhaji Saganuwan and Bosha Joel Aondohulugh
}

Department of Veterinary Pharmacology and Toxicology, Federal University of Agriculture,Makurdi, Benue State, Nigeria.

Publication history: Received on 07 October 2019; revised on 25 October 2019; accepted on 29 October 2019

Article DOI: https://doi.org/10.30574/gscbps.2019.9.2.0194

\begin{abstract}
Due to the low cost and effectiveness of sulphadimidine against a wide variety of animal diseases, it is still being widely used in veterinary medicine. The present study was carried out to determine the effect of age on the pharmacokinetics of sulphadimidine in West African Dwarf (WAD) goats following intramuscular route of administration. Eight (8) WAD goats separated into two groups of four animals consisting of two males and two female goats each were used. Sulphadimdine sodium was administered at a dose of $100 \mathrm{mg} / \mathrm{kg}$ body weight. The goats in group one ( 3 months of age) and goats in group two ( 2 years old) were administered the drug on the right gluteal muscle. The pharmacokinetic parameters in the 3 months old WAD goats such as the maximum concentration (Cmax) (88.52 \pm 6.07$)$, elimination half life $(\mathrm{T} 1 / 2 \beta)(3.79 \pm 0.29 \mathrm{~h})$, volume of distribution $(\mathrm{Vd})(4.55 \pm 0.46 \mathrm{~L} / \mathrm{kg})$, total body clearance $(\mathrm{Cl})(0.77 \pm 0.09 \mathrm{~L} / \mathrm{kg} / \mathrm{h})$ and mean residence time (MRT) $(4.57 \pm 0.48 \mathrm{~h})$, were significantly $(\mathrm{p}<0.05)$ lower in comparison with Cmax (103. $59 \pm 7.56), \mathrm{T} 1 / 2 \beta(4.90 \mathrm{~h}), \mathrm{Vd}(13.03 \pm 1.58 \mathrm{~L} / \mathrm{kg}), \mathrm{Cl}(1.91 \pm 0.26 \mathrm{~L} / \mathrm{kg} / \mathrm{h})$ and MRT $(7.10 \pm 0.73 \mathrm{~h})$ of the $2 \mathrm{years}$ old WAD goats. The pharmacokinetic parameters of sulphadimidine in the 3 months old WAD goats were significantly different from that of the 2 years old WAD goats. This may be due to the difference in their body fat and water content.
\end{abstract}

Keywords: Sulphadimidine; Age; West African Dwarf goats; Pharmacokinetics

\section{Introduction}

Ageing is characterized by a steady decline in the functional reserve of multiple organs and systems, which can influence drug disposition [1]. The body fat of an animal increases with age while the total body water and body mass decreases with age. As a result, polar drugs are likely to have a lower apparent volume of distribution while fat soluble drugs will tend to have a higher volume of distribution with a prolonged half-life in older animals [2].

Sulphadimidine a synthetic antimicrobial drug is widely used in veterinary medicine. Sulphadimidine sensitive microorganisms require para-amino-benzoic acid (PABA) for the synthesis of folic acid which is essential for the synthesis of DNA and RNA. Since sulphadimidine is structurally related to PABA it acts by competitively inhibiting PABA which causes folic acid deficiency, resulting in arrest of bacteria growth and cell division [3]. Sulphadimidine is used in the treatment of urinary tract infections, meningitis, streptococcal pharyngitis, bacillary dysentery, toxoplasmosis, nocardiosis and chlamydiosis [4].

The disposition kinetics of sulphadimidine has been reported in cows, sheep and goats, guinea fowl, domestic chickens, ducks and turkeys [5-9]. The present study was carried out to determine the effect of age on the pharmacokinetics of sulphadimidine in West African Dwarf (WAD) goats following intramuscular administration.

\footnotetext{
${ }^{*}$ Corresponding author

E-mail address: agbojoseph222@gmail.com
} 


\section{Material and methods}

\subsection{Experimental animals}

This study was carried out in the Department of Veterinary Pharmacology and Toxicology, College of Veterinary Medicine, Federal University of Agriculture, Makurdi. The West African Dwarf (WAD) goats were purchased from local breeders in Makurdi metropolis. The goats were stabilized for two weeks prior to experimentation. They were fed on pasture and concentrate and water was provided ad libitum.

All the animals were handled according to the international guiding principle for biomedical research involving animals [International Council for Laboratory Animal Science [ICLAS] and Council for International Organization of Medical Sciences (CIOMS), (10) ], as approved by the College of Veterinary Medicine, Federal University of Agriculture, Makurdi, Ethical Committee.

\subsection{Experimental design and drug administration}

Eight (8) WAD goats were separated into two groups of four animals consisting of two males and two female goats each. Sulphadimdine sodium (33.3\%) (Shijiazhuang Guanghua Pharma. Co, ltd. China) was used at a dose of $100 \mathrm{mg} / \mathrm{kg}$ body weight. Goats in group one ( 3 months of age) had a mean weight of $4.00 \pm 0.41 \mathrm{~kg}$ while the goats in group two (2 years old) weighed $18.95 \pm 1.38 \mathrm{~kg}$. Sulphadimidine was administered to the animals on the right gluteal muscle.

\subsection{Blood sample collection}

Blood samples $(2.0 \mathrm{ml})$ were collected through the left and right jugular vein of each goat prior to sulphadimidine administration and at these time periods post drug administration 15, 30, $45 \mathrm{~min}$ and 1, 2, 4, 6, 8, 10, 12, 24, $48 \mathrm{~h}$. The samples were collected using $23 \mathrm{G}$ disposable needle and $2 \mathrm{ml}$ syringe into heparinized tubes. The samples collected were centrifuged at $3000 \mathrm{rpm}$ for $10 \mathrm{~min}$ and the plasma obtained and stored at $-20^{\circ} \mathrm{C}$ until analyzed.

\subsection{Determination of sulphadimidine in plasma}

Plasma concentration of sulphadimidine was determined by a modified chemical assay method described by [11]. The method is based on the diazotization of sulphadimidine and coupling with 8-OH quinoline in alkaline media to yield red coloured products with absorption maxima at $500 \mathrm{~nm}$. The procedure is briefly described below.

To $0.4 \mathrm{ml}$ of plasma in a $5 \mathrm{ml}$ glass test tube, $2 \mathrm{ml}$ of distilled water was added, followed by $0.6 \mathrm{ml}$ of $20 \%$ trichloroacetic acid (Guangdong, China). The resulting solution was mixed using a vortex mixer and centrifuged for 5 min. To the clear supernatant $(2.5 \mathrm{ml}), 0.15 \mathrm{ml}$ of $1.0 \%$ sodium nitrite (Kermel, China) was added, mixed and allowed to stand for $5 \mathrm{~min}$. Thereafter $0.25 \mathrm{ml}$ of $2.0 \%$ sulphamic acid (BDH Chemicals, England) was added, mixed and allowed to stand for $5 \mathrm{~min}$. This was followed by addition of $0.2 \mathrm{ml}$ of $0.5 \% 8-\mathrm{OH}$ quinoline (Sinopharm, China). The resulting solution was mixed and allowed to stand for $5 \mathrm{~min}$, followed by addition of $0.2 \mathrm{ml}$ of $20 \%$ sodium hydroxide (Qualikems, India). The resulting solution was mixed and the absorbance read using a UV-spectrophotometer (spectrum lab $23 \mathrm{~A}, 340-1000$ $\mathrm{nm}$ ) at a wavelength of $500 \mathrm{~nm}$. The linear calibration curve of sulphadimidine in plasma within the range of 1.25-20.0 $\mu \mathrm{g} / \mathrm{ml}$ was obtained by plotting absorbance on $\mathrm{y}$-axis against time on $\mathrm{x}$-axis. The calculation of the linear regression showed $\mathrm{R}^{2}=0.998$. The limit of detection (LOD) and limit of quantification (LOQ) of sulphadimidine in plasma were 0.08 and $0.24 \mu \mathrm{g} / \mathrm{ml}$ respectively. The intra-day and inter-day precision were 0.50 and $0.80 \%$ respectively.

\subsection{Calculation of pharmacokinetic parameters}

The pharmacokinetic parameters for individual animals were calculated using established pharmacokinetic equations [12-14] and pharmacokinetic software (Kinetica 5.0, Thermo Fischer Scientific). Micro $(\alpha, \beta)$ constants were determined from all the plotted graphs obtained from the generated data.

\subsection{Statistical analysis}

The data on plasma kinetics and pharmacokinetic parameters were presented in graphical and tabular form respectively. Plasma concentrations and pharmacokinetic parameters were presented as Mean \pm Standard Error of Mean (SEM) and analyzed by Student's t test paired using Graph Pad Prism 6.03 for windows at $5 \%$ level of significance. 


\section{Results}

The data for sulphadimidine in the 3 months and the 2 years old WAD goats best fitted a two compartment open model. The plasma concentration of the drug plotted semi- logarithmically against time after intramuscular administration in both groups is illustrated in figure 1. Plasma concentrations of free sulphadimidine were detected for $48 \mathrm{~h}$. The pharmacokinetic parameters in the 3 months old WAD goats such as the maximum concentration (Cmax) (88.52 \pm 6.07$)$, elimination half life $\left(\mathrm{T}_{1 / 2 \beta}\right)(3.79 \pm 0.29 \mathrm{~h})$, volume of distribution $(\mathrm{Vd})(4.55 \pm 0.46 \mathrm{~L} / \mathrm{kg})$, total body clearance $(\mathrm{Cl})$ $(0.77 \pm 0.09 \mathrm{~L} / \mathrm{kg} / \mathrm{h})$, mean residence time (MRT) $(4.57 \pm 0.48 \mathrm{~h})$, area under the curve from zero to $48 \mathrm{~h}\left(\mathrm{AUC}_{0-48}\right)$ $(471.80 \pm 78.68 \mu \mathrm{g} / \mathrm{ml} . \mathrm{h})$, area under the curve from zero to infinity $\left(\mathrm{AUC}_{0-\infty}\right)(478 \pm 0.9 \mu \mathrm{g} / \mathrm{ml} . \mathrm{h})$ and area under the moment curve (AUMC) $\left(22535.20 \pm 593.09 \mu \mathrm{g} / \mathrm{ml}^{2} \mathrm{~h}^{2}\right)$ were significantly $(\mathrm{p}<0.05)$ lower in comparison with Cmax $(103.59 \pm 7.56), \mathrm{T}_{1 / 2 \beta}(4.90 \mathrm{~h}), \mathrm{Vd}(13.03 \pm 1.58 \mathrm{~L} / \mathrm{kg}), \operatorname{Cl}(1.91 \pm 0.26 \mathrm{~L} / \mathrm{kg} / \mathrm{h}), \operatorname{MRT}(7.10 \pm 0.73 \mathrm{~h}), \quad(\mathrm{AUC} 0-48)$ $(954.92 \pm 75.23 \mu \mathrm{g} / \mathrm{ml} . \mathrm{h}),\left(\mathrm{AUC}_{0-\infty}\right)(962.91 \pm 75.09 \mu \mathrm{g} / \mathrm{ml} . \mathrm{h})$ and AUMC $\left(6909.98 \pm 1193.90 \mu \mathrm{g} / \mathrm{ml}^{2} \mathrm{~h}^{2}\right)$ of the $2 \mathrm{years}$ old WAD goats (table 1). Other kinetic parameters such as $\operatorname{Tmax}, \alpha, \mathrm{T}_{1 / 2 \alpha}$, MAT and $\beta$ were not significantly different $(\mathrm{p}>0.05)$ in both groups.

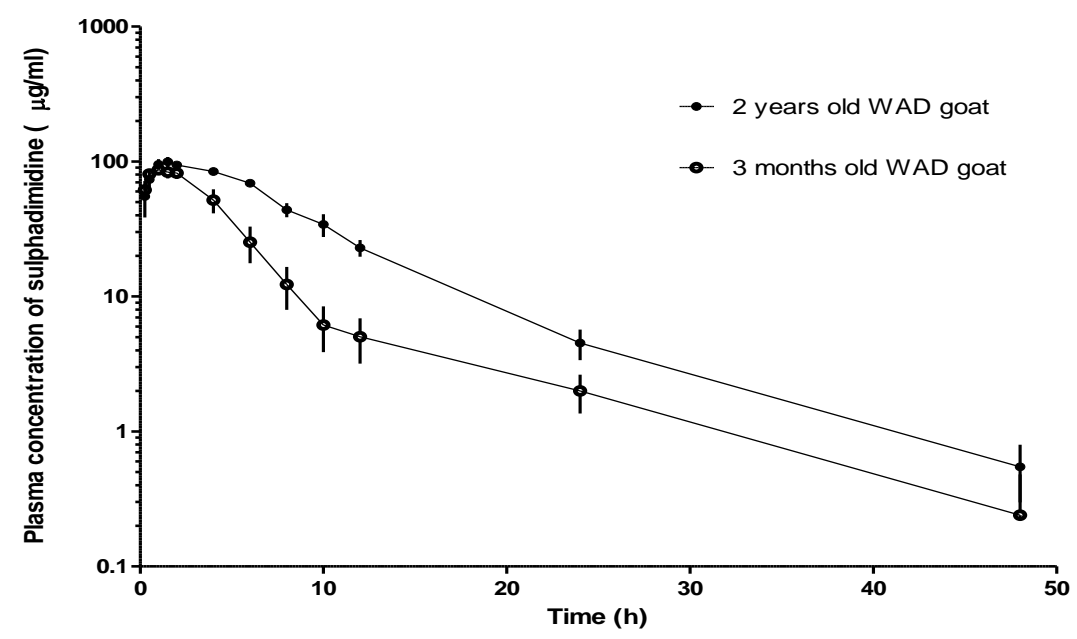

Figure 1 Mean plasma concentrations of sulphadimidine $(\mu \mathrm{g} / \mathrm{ml})$ in the 2 years and the 3 months old WAD goats following intramuscular treatment at $100 \mathrm{mg} / \mathrm{kg}$ body weight $(\mathrm{n}=4)$.

Table 1 Pharmacokinetic parameters of sulphadimidine in the 2 years and the 3 months old WAD goats following intramuscular treatment at $100 \mathrm{mg} / \mathrm{kg}$ body weight $(\mathrm{n}=4)$.

\begin{tabular}{lll}
\hline Kinetic parameters & 2 years WAD goat & 3 months WAD goat \\
\hline Cmax $(\mu \mathrm{g} / \mathrm{ml})$ & $103.59 \pm 7.56$ & $88.52 \pm 6.07^{\mathrm{a}}$ \\
$\operatorname{Tmax}(\mathrm{h})$ & $1.37 \pm 0.24$ & $1.00 \pm 0.20$ \\
$\alpha(1 / \mathrm{h})$ & $1.54 \pm 0.52$ & $1.08 \pm 0.25$ \\
$\mathrm{~T}_{1 / 2 \alpha}(\mathrm{h})$ & $0.66 \pm 0.21$ & $0.86 \pm 0.34$ \\
$\mathrm{MAT}(\mathrm{h})$ & $0.95 \pm 0.31$ & $1.25 \pm 0.48$ \\
$\beta(1 / \mathrm{h})$ & $0.15 \pm 0.02$ & $0.17 \pm 0.00$ \\
$\mathrm{~T}_{1 / 2 \beta}(\mathrm{h})$ & $4.90 \pm 0.69$ & $3.79 \pm 0.29^{\mathrm{a}}$ \\
$\mathrm{Vd}(\mathrm{L} / \mathrm{kg})$ & $13.03 \pm 1.58$ & $4.55 \pm 0.46^{\mathrm{a}}$ \\
$\mathrm{Cl}(\mathrm{L} / \mathrm{kg} / \mathrm{h})$ & $1.91 \pm 0.26$ & $0.77 \pm 0.09^{\mathrm{a}}$ \\
$\mathrm{MRT}_{\mathrm{A}}(\mathrm{h})$ & $7.10 \pm 0.73$ & $4.57 \pm 0.48^{\mathrm{a}}$ \\
$\mathrm{AUC} \mathrm{C}_{0-\mathrm{t}}(\mu \mathrm{gg} / \mathrm{ml} . \mathrm{h})$ & $954.92 \pm 75.23$ & $471.80 \pm 78.68^{\mathrm{a}}$ \\
$\mathrm{AUC}_{0-\infty}(\mu \mathrm{g} / \mathrm{ml} . \mathrm{h})$ & $962.91 \pm 75.09$ & $478.09 \pm 81.22^{\mathrm{a}}$ \\
$\mathrm{AUMC}\left(\mu \mathrm{g} / \mathrm{ml} \cdot \mathrm{h}^{2}\right)$ & $6909.98 \pm 1193.90$ & $2235.20 \pm 593.09^{\mathrm{a}}$ \\
\hline
\end{tabular}

Data are presented as mean $\pm S E M ; a=p<0.05$, paired student's $t$ test 
Cmax, maximum concentration; Tmax, time of maximum concentration; $\alpha$, absorption rate constant; $\mathrm{T}_{1 / 2 \alpha}$, absorption half-life; $\beta$, elimination rate constant; $\mathrm{T}_{1 / 2 \beta}$, elimination half-life; $\mathrm{Vd}$, volume of distribution; $\mathrm{Cl}$, total body clearance; $\mathrm{MRT}$, mean residence time; $\mathrm{AUC}_{0-\mathrm{t}}$, area under the plasma concentration vs time curve from 0 to time; $\mathrm{AUC}_{0-\infty}$, area under the plasma concentration vs time curve from 0 to infinite; AUMC, Area under the moment curve.

\section{Discussion}

The result of this study showed a biphasic elimination of sulphadimidine in the 2 years old and the 3 months old goats treated (figure 1) intramuscular with sulphadimidine. This is at variance with the findings in sheep and goat $[5,7,15]$ where the drug was eliminated by a single compartment model following intravenous administration. This could be due to specie or breed variation and differences in the route of administration. The findings however, agrees with those in dogs $[9,16-20]$ this may show that a drug's kinetic profile could differ from one animal to another even among the same species of animal [21].

The volume of distribution is the volume that would be required to contain the amount of drug present in the body at the same concentration as in the plasma or a factor that relates the amount of drug in the body to the concentration of drug in the plasma [22]. This gives information on a drug's distribution in the body. In the present study the 2 years old WAD goat treated with sulphadimidine had a Vd of $13.03 \pm 1.58 \mathrm{~L} / \mathrm{kg}$ as against $4.55 \pm 0.46 \mathrm{~L} / \mathrm{kg}$ for the 3 months old WAD goats. The high volume of distribution in the older animals is an indication of more extensive penetration into the body fluids and tissues of the body. This high volume of distribution shows that the agent may be distributed to both interstitial and intracellular fluid spaces. The significantly $(p<0.05)$ lower volume of distribution obtained in the 3 months old WAD goats treated with sulphadimidine could be due to the higher total body water in younger animals or humans compared to that of older animals or humans [23]. A drug's volume of distribution reflects the extent to which it is present in the extravascular tissues and not in plasma. Volume of distribution may vary widely depending on the relative degree of its binding to plasma and tissue proteins in comparison to the adult.

The total body clearance reflects the elimination of the drug from the body [24]. The higher the drug concentration in plasma, the more the drug is presented for elimination. Therefore, clearance is the coefficient of proportionality between plasma drug concentration and elimination [24]. Total body clearance of sulphadimidine in the 2 years old WAD goats was significantly $(\mathrm{p}<0.05)$ higher $(1.91 \pm 0.26 \mu \mathrm{g} / \mathrm{ml})$ as against that of the 3 months old WAD goats $(0.77 \pm 0.09 \mu \mathrm{g} / \mathrm{ml})$. This suggests that more of the drugs are presented to the metabolic and excretory organs at any point in time for metabolism and excretion in the older goats, compared to the 3 months old goats.

The area under the concentration-time curve (AUC) is the integral of the plasma drug concentration-time curve [24]. The AUC reflects the actual exposure to the drug after administration of a dose of the drug. It is dependent on the rate of elimination and the dose administered and inversely proportional to the drug clearance [24]. In the present study, the AUC in the 2 years old goats was significantly $(\mathrm{p}<0.05)$ greater than that of the 3 months old goats. This may indicate the total amount of drug absorbed into the body. In the present study the Cmax for the 2 years old goats was higher than that of the 3 months old goats. AUC clinically is useful to determine the concentration of a drug over a time interval [25]. AUC and Cmax are the two parameters used often to define the systemic exposure of a drug.

The elimination half-lives of sulphadimidine reported in this study for the 2 years $(4.90 \pm 0.69 \mathrm{~h})$ and the 3 months old $(3.97 \pm 0.29 \mathrm{~h}) \mathrm{WAD}$ goats were closer to those reported in 18 weeks kid $(3.9 \pm 1.21 \mathrm{~h})$ [26], sheep $(4.72 \pm 0.26 \mathrm{~h})$ [27] and sheep (3.64 h and $3.92 \mathrm{~h}$ ) [28]. However, the elimination half-lives of sulphadimidine reported in this study was shorter than that of cattle $(9.46 \pm 0.93 \mathrm{~h}, 9.87 \pm 1.20 \mathrm{~h}, 8.32 \pm 0.96 \mathrm{~h}$ and $7.45 \pm 1.05 \mathrm{~h})$ [29], goat $(7.24 \pm 0.59 \mathrm{~h})$ [9] and sheep $(9.5 \mathrm{~h})$ [30]. These variations may be due to variations in specie, breed, analytical techniques and curve fitting strategies.

\section{Conclusion}

It can be concluded that age as a factor altered the pharmacokinetic parameters of sulphadimidine in WAD goats probably due to differences in their body fat and water content. The reduced volume of distribution and elimination rate should be considered when treating young goats. 


\section{Compliance with ethical standards}

\section{Acknowledgments}

We acknowledge the help received from Mr. James Onoja and Mrs. Funke Momoh of the Veterinary Teaching Hospital, University of Agriculture, Makurdi in the analysis of the plasma samples.

\section{Disclosure of conflict of interest}

The authors declare that they have no competing interests.

\section{References}

[1] Shi S and Klotz U. (2011). Age related changes in Pharmacokinetics, 12, 601-610.

[2] Mangoni AA and Jackson SDH. (2003). Age-related changes in pharmacokinetics and pharmacodynamics: basic principles and practical applications. British Journal of Clinical Pharmacology, 57, 6-14.

[3] Lavanya R. (2017). Sulphonamides: A Pharmaceutical Review. International Journal of Pharmaceutical Science Invention, 6, 1-3.

[4] Kaur L, Arora V, Arora P. et al. (2018). A review: biological significance of sulfonamides, 7, 413-422.

[5] Nawaz M and Khan FH. (1979). Pharmacokinetics and urinary excretion of sulphadimidine in sheep and goats. Journal of Veterinary Pharmacology and Therapeutics, 2, 129-132.

[6] Nouws J FM, Vree TB, Aerts R and Grodel J. (1986). Pharmacokinetics and residues of sulphadimidine, its N4acetyl and hydroxyl metabolites in food producing animals. Archiv für Lebensmittel hygiene, 37, 57-84.

[7] Onyeyili PA, Egwu GO, Apampa OA and Ameh J. (1997). Elimination of sulphadimidine from edible tissues and blood of guinea fowl, domestic chickens and ducks. Bulletin of African Animal Health and Production, 45, 225229.

[8] Agbo JO, Saganuwan SA and Onyeyili PA. (2016). Comparative Pharmacokinetics of Intramuscular Sulphadimidine in Non-starved and Starved Grower Turkeys (Meleagris gallopavo). Journal of Pharmacology and Toxicology, 11, 11-19.

[9] Akogwu EI, Saganuwan SA and Onyeyili PA. (2017). Effects of Piroxicam on Pharmacokinetics of Sulphadimidine in West African Dwarf Male and Female Goats (Capra hircus).Pharmaceutical Analytica Acta 8, 555.

[10] ICLAS and CIOMS (2012). Internation guiding principles for biomedical research involving animals.

[11] Nagaraja P, Naik SD, Shrestha AK. et al. (2007). A sensitive spectrophotometric method for the determination of sulfonamides in pharmaceutical preparations. Acta Pharmaceutica, 57, 333-342.

[12] Saganuwan SA. (2012). Principles of Pharmacological Calculations, Ahmadu Bello University Press, Zaria.

[13] Aliu YO. (2007). Veterinary Pharmacology, 1st ed., Tamazzan Publishing Company Limited, Zaria.

[14] Baggot JD. (2001).The Physiological Basis of Veterinary Clinical Pharmacology, Blackwell Science, Oxford, UK.

[15] Heath GE, Kline DA, Bamess CJ and Showalter DH. (1975). Elimination of sulphamethazine from edible tissues, blood, urine and feces of turkey poults. American Journal of Veterinary Research 36, 913-197.

[16] Nawaz M. (1980). Pharmacokinetics and dosage of sulphadimidine in dogs. Journal of Veterinary Medicine, 26, 75-80.

[17] Saganuwan SA, Elsa, AT and Mahammad BY. (2003). Disposition kinetics of sulphadimidine in Nigerian mongrel dogs. Journal of Scientific and Industrial Studies, 1, 35-38.

[18] Onyeyili PA, Ogundele 00 and Sanni S. (2000). Effect of starvation on the elimination kinetics of sulphadimidine in Broiler chickens. Nigerian Journal of Experimental and Applied Biology, 1, 25-28.

[19] Nielsen and Rasmussen F. (1977). Half-life, volume of distribution and protein binding for some sulphonamides in cows. Veterinary Research Science, 22, 205-208. 
[20] Atef MM, Elsayed MCA and Ramadan A. (1981). Pharmacokinetics of some sulphonamides in buffaloes. Zentralblatt fur Veterinamedizin 28, 122-130.

[21] Nilsson-Ehle P, Yosikawa T and Oka C. (1960). Quantification of antibiotics using HPLC tetracycline. Antimicrobial Agents and Chemotherapy, 9, 745-760.

[22] Gustafson DL and Bradshaw-Pierce EL. (2011). Fundamental concepts in Clinical Pharmacology.

[23] Buxton ILO. (2006). Pharmacokinetics and Pharmacodynamics: The dynamics of drug absorption, distribution, action and elimination: In Goodman and Gilman's Pharmacological Basis of Therapeutics. $11^{\text {th }}$ ed. Mc Graw-Hill Company.

[24] Bourne DWA. (2010). Method of residuals.

[25] Baggot JD. (1977). Principles of Drug Disposition in Domestic Animals the Basis of Veterinary Clinical Pharmacology, W.B. Saunders Philadelphia.

[26] Nouws JFM, Mevius D, Vree TB and Degen M. (1989). Pharmacokinetics and renal clearance of sulphadimidine, sulphamerazine and sulphadiazine and their N4-acetyl and hydroxy metabolites in pigs, Veterinary Quarterly 11, 78-86.

[27] Elsheikh HA, Ali BH, Homeida AM et al. (1991). Pharmacokinetics of antipyrine and sulphadimidine (sulfamethazine) in camels, sheep and goats. Journal of Veterinary Pharmacology and Therapeutics 14, 269-275.

[28] Nawaz M and Nawaz R. (1983). Pharmacokinetics and urinary excretion of sulphadimidine in sheep during summer and winter.Veterinary Record, 112, 379-381.

[29] Eduardo EB, Diego CD, Eduardo P et al. (2008). Effects of age on the pharmacokinetics of single dose sulfamethazine after intravenous administration in cattle. Veterinary Research Communications, 32, 509-519.

[30] Youssef SA, El-Gendi AYI, El-Sayed MGA et al. (1981). Some pharmacokinetic and biochemical aspects of sulphadiazine and sulphadimidine in ewes. Journal of Veterinary Pharmacology and Therapeutics, 4, 173-182.

\section{How to cite this article}

Agbo JO, Onyeyili PA, Saganuwan SA and Bosha JA. (2019). Effect of age on the pharmacokinetics of sulphadimidine in West African Dwarf (WAD) goats following a single intramuscular administration. GSC Biological and Pharmaceutical Sciences, 9(2), 44-49. 